\title{
Perlindungan Hak Reproduksi Perempuan di Provinsi Riau
}

\author{
Nabella Puspa Rani
}

Fakultas Hukum Universitas Lancang Kuning

Email: nabellapusparani@unilak.ac.id

\begin{abstract}
One form of rights that every person is the right to health. Health is an important aspect of Human Rights (HAM), which is written in the Declaration of Human Rights by the United Nations (UN) in 1948. The issue of women's reproductive rights is part of the concept of Human Rights. The significance of the right to health is to provide duty and responsibility on the government to create the conditions that allow every individual to live a healthy life, with efforts to provide adequate health care facilities and affordable health care for the community. Women's reproductive health is one thing to be considered given the death rate among a lot of women. So it takes some regulations on the fulfillment of reproductive health rights for women, as well as the efforts undertaken by the government in implementing and protecting women's reproductive health rights.
\end{abstract}

Keywords: Human Rights, Women's Rights, Reproductive Health

\begin{abstract}
Abstrak
Salah satu bentuk hak yang dimiliki setiap orang adalah hak kesehatan. Kesehatan merupakan aspek penting dari Hak Asasi Manusia (HAM), yang dituliskan dalam Deklarasi Hak Asasi Manusia oleh Perserikatan BangsaBangsa (PBB) tahun 1948. Persoalan mengenai hak reproduksi perempuan merupakan bagian dari konsep Hak Asasi Manusia. Makna dari hak kesehatan ini adalah memberikan tugas dan tanggungjawab pada pemerintah untuk menciptakan kondisi yang memungkinkan setiap individu agar hidup sehat, dengan upaya menyediakan sarana pelayanan kesehatan yang memadai dan pelayanan
\end{abstract}


kesehatan yang terjangkau bagi masyarakat. Kesehatan reproduksi perempuan merupakan salah satu hal yang harus diperhatikan mengingat angka kematian banyak dari kalangan perempuan. Sehingga dibutuhkan beberapa regulasi tentang pemenuhan hak kesehatan reproduksi bagi perempuan, serta upaya-upaya yang dilakukan oleh pemerintah dalam melaksanakan dan melindungi hak kesehatan reproduksi perempuan.

Kata Kunci: Hak Asasi Manusia, Hak Perempuan, Kesehatan Reproduksi

\section{A. Pendahuluan}

\section{Latar Belakang}

Persoalan mengenai hak reproduksi perempuan merupakan bagian dari konsep Hak Asasi Manusia. Perkembangan Hak Asasi Manusia memberikan dampak terhadap konsep HAM itu sendiri, yang dibagi dalam dua ide dasar. Pertama, pandangan yang berpijak pada keyakinan bahwa tiap manusia lahir dengan hak-hak individu yang tidak dipisahkan darinya, dan kedua pandangan yang menekankan kewajiban masyarakat dan negara untuk menjamin tidak saja kebebasan dan kesempatan bagi warga negara, tetapi juga memastikan bahwa warga negara mampu memperoleh, melaksanakan kebebasan, dan apa yang menjadi haknya. ${ }^{1}$

Salah satu bentuk hak yang dimiliki setiap orang adalah hak kesehatan. Kesehatan merupakan aspek penting dari Hak Asasi Manusia (HAM), yang dituliskan dalam Deklarasi Hak Asasi Manusia oleh Perserikatan Bangsa-Bangsa (PBB) tahun 1948. Pasal 25 ayat (1) menuliskan tentang "'Setiap orang berhak atas taraf kehidupan yang memadai untuk kesehatan dan kesejahteraan dirinya sendiri dan keluarganya." Sebagai Hak Asasi Manusia, hak kesehatan merupakan hak yang melekat pada seseorang karena kelahirannya sebagai manusia, bukan karena pemberian

1 Tapi Omas Ihromi (ed), Penghapusan Diskriminasi Terhadap Perempuan, PT.Alumni, Bandung, 2006, h. 302-303.

${ }^{2}$ DUHAM 1948 
seseorang atau negara, dan oleh sebab itu tentu saja hak ini tidak dapat dicabut dan dilanggar.

Makna dari hak kesehatan ini adalah memberikan tugas dan tanggungjawab pada pemerintah untuk menciptakan kondisi yang memungkinkan setiap individu agar hidup sehat, dengan upaya menyediakan sarana pelayanan kesehatan yang memadai dan pelayanan kesehatan yang terjangkau bagi masyarakat.

Kondisi Indonesia saat ini, sedang menghadapi tantangan terhadap persoalan kesehatan, seperti tingginya angka kematian bayi dan angka kematian pada ibu melahirkan, rendahnya kesadaran masyarakat tentang kesehatan reproduksi, serta masih cukup tingginya laju pertumbuhan penduduk. Persoalan kematian pada ibu melahirkan berawal dari rendahnya pengetahuan terhadap kesehatan reproduksi. Selain itu juga, terhadap perempuan sendiri harusnya lebih proaktif menjaga kesehatan reproduksi agar tidak menimbulkan kematian yang disebabkan oleh berbagai penyakit kelamin seperti kanker serviks, kista, myom, dan sejenisnya. Hal ini tentunya akan berdampak pada angka kependudukan dalam negara.

Keprihatinan akan permasalahan kependudukan melahirkan sebuah konsep pembangunan berwawasan kependudukan atau konsep pembangunan yang berkelanjutan. Dari sini pula lahir kesadaran dunia untuk mengurangi masalah kemiskinan dan keterbelakangan melalui pendekatan kependudukan. Langkah pertama dan merupakan strategi yang monumental adalah kesadaran lebih dari 120 pemerintah/negara yang berjanji melalui konferensi internasional tentang pembangunan dan kependudukan (ICPD) di Cairo pada tahun 1994 untuk bersama-sama menyediakan pelayanan kesehatan reproduksi bagi semua orang tanpa diskriminasi "Secepat mungkin paling lambat tahun 2015" (BKKBN-FE UI, 2004).

Indonesia sebagai negara yang juga menandatangani ICPD, berkewajiban untuk turut serta memberikan pemahaman dan perlindungan atas hak kesehatan reproduksi, khususnya perempuan. Hal ini dikarenakan, tingginya angka kematian perempuan yang disebabkan dari penyakit seksual dan penyakit kelamin lainnya. 
Provinsi Riau juga mengalami persoalan pada angka kematian ibu melahirkan. Berdasarkan data yang diperoleh, terjadi peningkatan angka kematian ibu melahirkan tiap tahunnya, yaitu:

Tabel 1: Angka Kematian Ibu Melahirkan di Provinsi Riau

\begin{tabular}{|l|c|}
\hline \multicolumn{1}{|c|}{ TAHUN } & JUMLAH \\
\hline 2013 & 135 jiwa \\
\hline 2014 & 158 jiwa \\
\hline Januari-Mei 2015 & 86 jiwa \\
\hline
\end{tabular}

Sumber: Berita Antara Riau, Oktober 2015

Angka kematian ibu juga merupakan salah satu sasaran yang memerlukan upaya keras untuk mencapai target 102 per 100.000 kelahiran hidup pada tahun 2015. Angka kematian ibu di Provinsi Riau menurun dari 390 pada tahun 1991 menjadi 228 per 100.000 kelahiran hidup pada tahun 2007 . Tetapi meningkat lagi menjadi 359 per 100.000 kelahiran pada tahun $2012 .^{3}$

Selain itu juga, indikator lain kematian perempuan di Provinsi Riau disebabkan oleh kanker serviks. Berikut data kematian perempuan penderita kanker serviks yang penulis peroleh:

Tabel 2. Penderita Kanker Serviks berdasarkan Rekam Medik RSUD Arifin Achmad

\begin{tabular}{|l|l|}
\hline TAHUN & PENDERITA KANKER SERVIKS \\
\hline 2009 & 66 orang \\
\hline 2010 & 113 orang \\
\hline 2011 & 132 orang \\
\hline 2012 & 89 orang \\
\hline 2013 & 109 orang \\
\hline
\end{tabular}

Data olahan tahun 2015

\footnotetext{
${ }^{3}$ Profil Dinas Kesehatan Provinsi Riau tahun 2015.
} 
Masih tingginya angka kematian ibu melahirkan dan kematian perempuan penderita kanker serviks di Provinsi Riau, memberikan keprihatinan terhadap penulis untuk mengkaji tentang pemenuhan hak kesehatan reproduksi di Indonesia, khususnya Provinsi Riau.

\section{Rumusan Masalah}

Penulis menyadari masih banyak persoalan terkait dengan perempuan di Provinsi Riau, hanya saja dalam kesempatan ini penulis fokus terhadap persoalan perlindungan kesehatan reproduksi pada perempuan, sebagai implementasi hak kesehatan yang merupakan bagian dari Hak Asasi Manusia.

\section{Metode Penelitian}

\section{a. Jenis Penelitian}

Jenis penelitian yang akan laksanakan adalah penelitian sosiologis yuridis, yaitu penelitian yang dilakukan dengan cara mengadakan identifikasi hukum dan bagaimana efektifitas pelaksanaan hukum itu berlaku di masyarakat. ${ }^{4}$ Penelitian ini akan melihat fakta di lapangan berdasarkan peraturan perundang-undangan yang berlaku yang berkaitan dengan pemenuhan hak reproduksi di Provinsi Riau.

\section{b. Lokasi Penelitian}

Lokasi penelitian adalah Provinsi Riau.

\section{c. Responden}

1) Kepala Dinas Kesehatan Provinsi Riau;

2) Kepala RSUD Arifin Ahmad;

3) Kepala BKKBN Provinsi Riau;

4) Masyarakat

\section{d. Sumber Data}

Data yang digunakan dalam penelitian ini adalah:

4 Soejono Soekanto, Pengantar Penelitian Hukum, Ui-Press, Jakarta, 2006, h.76. 
1) Data primer adalah data yang diperoleh secara langsung dari responden dengan menggunakan alat pengumpulan data berupa wawancara dan kuisioner;

2) Data sekunder adalah data yang diperoleh dari peraturan perundang-undangan dan literaturliteratur yang berhubungan dengan masalah pokok dari penelitian ini.

3) Data tersier adalah data yang diperoleh melalui kamus, ensiklopedi dan sebagainya yang berfungsi untuk mendukung data primer dan sekunder.

\section{e. Teknik Pengumpulan Data}

Adapun teknik pengumpulan data yang peneliti gunakan sebagai berikut:

1) Observasi

Yaitu pengumpulan data yang dibutuhkan dalam penelitian ini dengan cara pengamatan langsung terhadap objek penelitian yaitu upaya pemerintah dalam pemenuhan hak kesehatan reproduksi di Provinsi Riau.

2) Wawancara

Yaitu mengadakan proses tanya jawab langsung kepada responden dengan pertanyaan-pertanyaan non struktur terkait permasalahan.

3) Kuisioner

Yaitu alat pengumpul data berupa daftar pertanyaan yang telah peneliti sebarkan atau peneliti berikan kepada responden, kemudian peneliti kumpulkan kembali untuk diolah.

4) Kajian Kepustakaan

Yaitu untuk memperlengkap data yang dibutuhkan dalam penelitian ini, peneliti melakukan pengumpulan data dengan literatur kepustakaan yang mempunyai hubungan logis dengan permasalahan yang sedang diteliti. Hal ini dilakukan untuk mencari data sekunder sebagai pendukung terhadap data primer. 


\section{B. Kajian Teoritik}

\section{Hak Asasi Manusia}

Hak Asasi Manusia muncul seiring lahirnya manusia itu sendiri. Hak Asasi Manusia ada untuk menjaga harkat dan martabat manusia sebagai insan terbaik di muka bumi ini. Hak Asasi Manusia merupakan hak kodrati setiap manusia. Hak Asasi Manusia atau hak dasar adalah sebutan dari hak elementer yang dipandang mutlak diperlukan bagi perkembangan individu. ${ }^{5}$ Selain bersifat universal hak-hak tersebut juga tidak dapat dicabut oleh siapapun termasuk Negara. Hak itu melekat sepanjang manusia itu hidup. Istilah Hak Asasi Manusia (selanjutnya disingkat HAM) telah dikenal dalam praktek kehidupan bernegara baik di tingkat nasional maupun internasional.

Pada awalnya, istilah tersebut merupakan terjemahan dari kata dalam bahasa Prancis droits de I'homme yang terjemahan harfiahnya adalah hak-hak manusia. Pernyataan ini digunakan pula oleh PBB yang di dalam bahasa Inggrisnya disebut dengan istilah fundamental human rights yang disingkat dengan istilah human rights. ${ }^{6}$ Dewasa ini konsep HAM telah diterima secara hampir universal sebagai norma hukum yang dituangkan dalam konstitusi maupun peraturan perundang-undangan lainnya suatu negara. Bahkan, beberapa pengamat seperti Wissbrodt dan Vasak menyatakan bahwa HAM telah menjadi ideologi universal. ${ }^{7}$ Pernyataan ini seolah-olah menganggap bahwa hakikat HAM sudah jelas dan tidak perlu diperdebatkan lagi.

Pernyataan ini hendaknya ditanggapi secara kritis, sebab kejelasan persepsi mengenai hakikat HAM akan menghasilkan konsekuensi-konsekuensi praktis sejauh

${ }^{5}$ Peter R. Baehr, Hak-Hak Asasi Manusia Dalam politik Luar Negeri, diterjemahkan oleh Soemardi,, Yayasan Obor Indonesia, Jakarta, 1998, h. 3.

6 Ahmad Kosasi, HAM Dalam Perspektif Islam; Menyingkap Persamaan Dan Perbedaan Antara Islam Dan Barat, Salemba Diniyah, Jakarta, 2003, h. xviii.

${ }^{7}$ Scott Davidson, Hak Asasi Manusia: Sejarah, Teori Dan Praktek Dalam Pergaulan Internasional, diterjemahkan oleh A. Hadyana Pudjaatmaka, Pustaka Utama Grafiti, Jakarta, 1994, h. 33 
menyangkut proteksi terhadap HAM itu sendiri. Misalnya, masalah apakah hak ekonomi, sosial dan budaya benar-benar adalah hak asasi ataukah sekadar target aspirasi. Jika hak-hak itu hanya merupakan target aspirasi, maka tidak seorang pun dapat dengan sah menuntut pemerintahnya untuk memberikan perlindungan bagi pelaksanaan hak tersebut secara mutlak. Hak-hak itu dapat sekedar dipandang sebagai tuntutan untuk memperoleh kehidupan yang lebih baik, yang mungkin dipenuhi oleh pemerintah jika kondisi ekonomi telah baik dan stabil pada suatu waktu yang tidak dapat ditentukan. Namun, jika hak-hak tersebut merupakan hak asasi yang tidak boleh disimpangi dalam kondisi apapun, maka pemerintah berkewajiban untuk memberikannya melalui suatu mekanisme pelaksanaan yang tepat. ${ }^{8}$

Oleh karena itu, HAM harus diuraikan secara jelas, baik dalam segi definisinya secara etimologi maupun terminologi, eksistensi, nilai serta hubungan antara hak yang satu dengan hak yang lain, dan hubungannya dengan norma hukum pada umumnya. Secara etimologi, hak asasi manusia diartikan sebagai hak dasar atau hak pokok seperti hak hidup dan hak mendapatkan perlindungan. ${ }^{9}$ Sedangkan secara terminologi, terdapat berbagai pendapat para pakar hukum maupun legislator tergantung perspektif masing-masing pihak dalam mengartikan HAM. Meskipun demikian, pemaknaan terhadap HAM tersebut tidak bisa dilepaskan terhadap perdebatan pengertian tentang hak. Sampai saat ini pun, pengertian hak belum ditemui secara lengkap dan memuaskan. ${ }^{10}$

Hukum dan hak adalah dua hal yang berbeda namun saling berhubungan. Hak obyektif atau hukum dipandang sebagai peraturan atau norma, sedangkan hak subyektif atau

\footnotetext{
${ }^{8}$ Ibid.

${ }^{9}$ Tim Penyusun Kamus Departemen Pendidikan Dan Kebudayaan
} RI, Kamus Besar Bahasa Indonesia, Jakarta, 1988, h. 191.

${ }^{10}$ Zoelfirman, Kebebasan Berkontrak Versus Hak Asasi Manusia (Analisis Yuridis Hak Ekonomi, Sosial, Dan Budaya), UISU Press, Medan, 2003, h. 57. 
hak didefinisikan sebagai kepentingan atau kehendak. ${ }^{11}$ Menurut Paton, hak ditinjau dari sifatnya mempunyai tiga unsur yang saling terkait yaitu perlindungan, kehendak dan kepentingan. Suatu hak mempunyai sifat hukum sehingga hak tersebut dilindungi oleh sesuatu sistem hukum.Dengan demikian hak itu adalah untuk perlindungan. Kemudian, Si pemegang hak melaksanakan kehendaknya dengan cara tertentu, dengan demikian hak bersifat mempunyai kehendak, dan kehendak itu diarahkan untuk memuaskan kepentingan tertentu. Oleh karena itu, hak juga mempunyai sifat merupakan kepentingan. ${ }^{12}$ Senada dengan pendapat ini, Sudikno Mertokusuma menyatakan bahwa hak merupakan kepentingan yang pada hakikatnya mengandung kekuasaan yang dijamin dan dilindungi oleh hukum dalam melaksanakannya. ${ }^{13}$

\section{Hak Perempuan}

Selama lebih dari 6000 tahun, sejarah wanita diliputi unsur kegelapan dan kepedihan. Wanita cuma hanyut dalam arus zaman dan tertekan hidupnya oleh macam-macam belenggu sebagai produk dari kekuasaan kaum pria. Macammacam usaha kaum wanita untuk mendapatkan kedudukan sosial yang lebih tinggi banyak yang kandas dan sia-sia belaka. Sehingga mereka tidak mendapatkan kesempatan untuk mengembangkan bakat kemampuannya secara wajar dan proposional. ${ }^{14}$ Namun zaman sudah berubah, kaum perempuan sudah mulai bangkit untuk memperjuangkan hakhaknya bahkan sudah meluas mencapai perjuangan secara internasional yang telah menghasilkan bermacam-macam

${ }^{11}$ Hans Kelsen, General Theory of Law and State, diterjemahkan oleh Raisul Mutaqien menjadi Teori Umum tentang Hukum dan Negara, penerbit Nuamedia \& penerbit Nuansa, Bandung, 2006, h.114.

12 George Ehitecros Paton, A Text-Book of Jurisprudance, Off Gray's inn, Barrister et law vice-Chancellor of the University of malbourne, terjemahan G. Soedarsono, dkk, Jajasan B.P. Gajah Mada Jogjakarta,t.t., h. 23-38.

13 Sudikno Mertokusumo, Mengenal Hukum; Suatu Pengantar, Liberty, Yogyakarta, 1999, h. 43. 2007, h. 2

${ }^{14}$ Kartini Kartono, Psikologi Wanita 2, Mandar Maju, Bandung, 
konvensi internasional yang mengakomodir perlindungan terhadap hak-hak perempuan.

Semua hak dapat dinalarkan melalui penalaran tentang hak asasi manusia. Namun ada hak asasi manusia yang mempunyai kekhususan yaitu hak perempuan. Sekalipun perempuan adalah juga manusia, sehingga hak asasinyapun adalah Hak Asasi Manusia. Sebelum adanya Deklarasi Universal Hak Asasi Manusia Perserikatan Bangsa Bangsa, seorang putri Indonesia yang bernama Kartini pada tanggal 10 Juni 1901, menulis surat kepada rekannya di Negeri Belanda yang menceritakan tentang harapan akan adanya emansipasi antara kaum perempuan dan laki-laki, kebebasan berpikir mereka dan sebagainya. Disini Kartini sudah membuka sebuah human right discourse (wacana hak asasi manusia), meskipun artikulasi mengenai hak-hak asasi masih amat sumir. ${ }^{15}$ Kalau melihat defenisi pada Pasal 1 Deklarasi sedunia tentang HAM yang menyatakan bahwa setiap orang dilahirkan merdeka dan punya martabat dan hak yang sama, harusnya kondisi yang disebutkan tersebut harus juga melekat pada kaum perempuan sebagai bagian dari umat manusia. Namun sejarah telah membuktikan, bahwa perempuan masih diperlakukan tidak sama dengan laki-laki yang berakibat pada ketidakberdayaan perempuan melawan dominasi laki-laki. Isu perempuan tidak boleh lagi dianggap sebagai isu marjinal (pinggiran), namun harus merupakan isu penting dimana negara harus ikut andil dalam pemecahannya. Dimulai dari memasukkan konsep-konsep persamaan hak antara laki-laki dan perempuan dalam hukum tertulis negara, sampai mengawasi pelaksanaan dari peraturan tersebut.

Kekerasan terhadap perempuan berusia sama dengan usia peradaban manusia. Kemudian masalah ini menjadi perhatian internasional pada tahun 1975, saat PBB menyelenggarakan konferensi dunia yang pertama tentang perempuan di Mexico City. Kekerasan berdasarkan gender menjadi ketetapan saat PBB menggelar tahun dasawarsa perempuan (1976-1985) dan menjadi prioritas masalah dalam pertengahan tahun 1980an. Peningkatan kepedulian terhadap

${ }^{15}$ Koesparmono Irsan, Hukum dan Hak Asasi Manusia, Yayasan Brata Bhakti, Jakarta, 2009, h.37. 
korban dari kekerasan dan keperluan untuk perubahan disuarakan oleh badan-badan PBB dan LSM. Pada konferensi PBB yang kedua dan ketiga tentang perempuan, issues tentang kekerasan terhadap perempuan mendapatkan momentumnya dengan adanya desakan untuk membuat aturan-aturan baik yang bersifat internasional, lebih-lebih yang bersifat nasional guna menanggulangi insiden-insiden kekerasan terhadap perempuan ${ }^{16}$.

Pada tahun 1979, Sidang Umum PBB mengadopsi Convention on the Elimination of All Forms of Discrimination against woman (selanjutnya disingkatCEDAW). Lebih dari 130 Negara anggota PBB menyetujui untuk tunduk kepada sebagian besar isi konfensi. Mereka mengikatkan diri untuk melakukan penyelarasan hukum negaranya dengan memedomani CEDAW dan secara terencana melakukan upaya-upaya untuk meningkatkan kesederajatan dan kesamaan hak. Walaupun fokus dari konfensi adalah konprehensif, dan tidak pernah secara khusus menonjolkan segi kekerasan terhadap perempuan namun pada Artcle Sick mengutuk" all forms of traffic in women and exploitation of prostitution of women". Strategi Nairobi, yang tercipta pada tahun 1985, mengakui adanya genderspecific violence sebagai suatu bentuk penyalahgunaan. Strategi tersebut berbentuk suatu kerangka gerakan ditingkat nasional, regional dan internasional. Aturan-aturan hukum untuk mencegah kekerasan digariskan, syarat-syarat guna membangun mekanisme nasional untuk menangani problema-problema yang tumbuh juga dibentuk. Pada kajian yang dibuat strategi Nairobi dilancarkan, nampak bahwa kekerasan selalu berkaitan dan terlaksana karena adanya ketidaksamaan perlakuan dibidang sosial, politik, dan ekonomi. ${ }^{17}$

Pada tahun 1992, CEDAW, memformulasikan General Recommendation 19, yang secara khusus menggolongkan gender basic violence sebagai kekerasan yang ditujukan kepada perempuan karena dia adalah seorang perempuan atau violence that affects women disproportionately and its

\footnotetext{
${ }^{16}$ Ibid, h. 38.

${ }^{17}$ Ibid, h. 39
} 
discriminatory. Deklarasi Viena mengenai hak asasi manusia tahun 1993 (Pasal 18 dan 38) menyebutkan bahwa kekerasan terhadap perempuan adalah juga pelanggaran terhadap hak asasi manusia. The Declaration on the Eliminating of Violence against Women diadopsi oleh Sidang Umum PBB pada akhir tahun 1993, atas rekomendasi dari Commission on the Status of Women. Deklarasi tersebut menekankan bahwa kekerasan terhadap perempuan adalah merupakan bagian dari pelanggaran atas hak asasi manusia dan merekomendasikan strategi yang harus dilaksanakan oleh negara anggota dan badan-badan khusus PBB untuk menghilangkan kekerasan tersebut. ${ }^{18}$

Konvensi-konvensi internasional tentang hak asasi manusia, pada prinsipnya adalah suatu perangkat perlindungan yang komprehensif terhadap hak asasi manusia, termasuk hak perempuan, dimana setiap orang wajib menghormati hak asasi orang lain, moral, etika, dan tata tertib kehidupan berbangsa dan bernegara. Pada era globalisasi ini, perempuan tidak lagi hanya berkiprah diranah privat, tapi perlu diberi kesempatan untuk berkembang diranah publik sesuai dengan potensi dan kemampuannya. Sehingga perlu dilakukan langkah-langkah untuk memberdayakan perempuan, salah satunya dengan memasukkan pasal-pasal konvensi tersebut diatas dalam rumusan peraturan perundang-undangan negara dan mengawasi pelaksanaan dari peraturan tersebut.

\section{Hak Kesehatan Reproduksi}

Reproduksi secara sederhana dapat diartikan sebagai kemampuan untuk "membuat kembali". Dalam kaitannya dengan kesehatan, reproduksi diartikan sebagai kemampuan seseorang memperoleh keturunan (melahirkan). ${ }^{19}$ Menurut WHO dan ICPD, kesehatan reproduksi adalah keadaan sehat yang menyeluruh, meliputi aspek fisik, mental, dan sosial dan bukan sekedar tidak adanya penyakit atau ganggguan segala hal yang berkaitan dengan sistem reproduksi, fungsinya

${ }^{18}$ Ibid

19 Zora Adi Baso dan Judi Raharjo, Kesehatan Reproduksi Panduan bagi Perempuan, Pustaka Belajar, Sulawesi Selatan, 1999, h. 1. 
maupun proses reproduksi itu sendiri. ${ }^{20}$ Sesuai dengan defenisi tersebut pelayanan kesehatan reproduksi secara luas didefenisikan sebagai konstelasi metode, teknik dan pelayanan yang berkaitan dengan kesehatan reproduksi dengan cara mencegah dan memecahkan masalah kesehatan reproduksi.

Menurut Mariana Amiruddin, defenisi kesehatan reproduksi adalah sekumpulan metode, teknik, dan pelayanan yang mendukung kesehatan dan kesejahteraan reproduksi yang mencakup kesehatan seksual, status kehidupan dan hubungan perorangan, bukan semata konsultasi dan perawatan yang berkaitan dengan reproduksi dan penyakit yang ditularkan melalui hubungan seks. ${ }^{21}$

Menurut program kerja WHO ke IX (1996-2001) pada Mei 1994, masalah kesehatan reproduksi ditinjau dari pendekatan keluarga meliputi:

a. Praktik tradisional yang berakibat buruk semasa anakanak, seperti mutilasi genital, diskriminasi pada anak;

b. Masalah kesehatan reproduksi remaja, kemungkinan besar dimulai sejak masa kanak-kanak yang seringkali muncul dalam bentuk kehamilan remaja, kekerasan/pelecehan seksual dan tindakan seksual tidak aman;

c. Tidak terpenuhinya kebutuhan ber-KB, biasanya terkait dengan persoalan aborsi tidak aman;

d. Mortalitas dan morbiditas ibu dan anak (sebagai kesatuan) selama kehamilan, persalinan, dan masa nifas yang diikuti dengan malnutrisi anemia, bayi berat lahir rendah;

e. Infeksi Saluran Reproduksi (ISR), yang berkaitan dengan Penyakit Menular Seksual (PMS);

f. Kemandulan yang berkaitan dengan ISR/PMS

g. Sindrom pre dan post menopause (andropause), dan peningkatan resiko kanker organ reproduksi;

h. Kekurangan hormon yang menyebabkan osteoporosis dan masalah usia lanjut lainnya.

${ }^{20}$ Made Okara Negara, Mengurangi Persoalan Kehidupan Seksual dan Reproduksi Perempuan dalam Jurnal Perempuan cetakan No.41, Yayasan Jurnal Perempuan, Jakarta, 2005, h. 9.

${ }^{21}$ Layyin Mahfina, Elfi Yuliani Rohmah, Retno Widyaningrum, Remaja dan Kesehatan Reproduksi, STAIN Ponorogo, Yogyakarta, 2009, h. 38. 


\section{Pembahasan}

\section{Tinjauan Yuridis Terhadap Hak Kesehatan Reproduksi Perempuan}

Pasal 1 ayat (3) Undang-Undang Dasar 1945 menyatakan bahwa Indonesia adalah negara hukum. Sebagai salah satu negara hukum, maka berimplikasi pada penyelenggaraan segala aktifitas pemerintah dan negara yang harus berdasarkan pada hukum. Pelaksanaan pemenuhan dan perlindungan hak kesehatan reproduksi di Indonesia tidak terlepas pada aturan-aturan internasional, yaitu:

Tabel 3: Aturan Internasional terhadap

Hak Kesehatan Reproduksi

\begin{tabular}{|c|c|}
\hline No. & Regulasi dan Pasal Terkait \\
\hline 1. & $\begin{array}{l}\text { Deklarasi Universal Hak Asasi Manusia (Universal } \\
\text { Declaration of Human Rights) } 1948 \\
\text { 1. Hak kebebasan mencari jodoh dan membentuk } \\
\text { keluarga, } \\
\text { 2. Perkawinan harus dilaksanakan atas dasar suka } \\
\text { sama suka (Pasal 16). } \\
\text { 3. Hak kebebasan atas kualitas hidup untuk jaminan } \\
\text { kesehatan dan keadaan yang baik untuk dirinya dan } \\
\text { keluarganya (Pasal 25). }\end{array}$ \\
\hline 2. & $\begin{array}{l}\text { Konvensi Mengenai Penghapusan Segala Bentuk } \\
\text { Diskriminasi Terhadap Wanita (Convention on the } \\
\text { Elimination of All Forms of Discrimination Against } \\
\text { Women/CEDAW) } \mathbf{1 9 8 1} \\
\text { - Bagian III, Pasal } 10 \\
\text { Negara-negara Peserta wajib melakukan langkah- } \\
\text { tindak yang tepat untuk menghapus diskriminasi } \\
\text { terhadap wanita, guna menjamin bagi mereka hak- } \\
\text { hak yang sama dengan pria di bidang pendidikan, } \\
\text { khususnya guna menjamin persamaan antara pria } \\
\text { dan wanita: } \\
\text { (h) Memperoleh penerangan edukatif khusus untuk }\end{array}$ \\
\hline
\end{tabular}




\begin{tabular}{|c|c|}
\hline- & 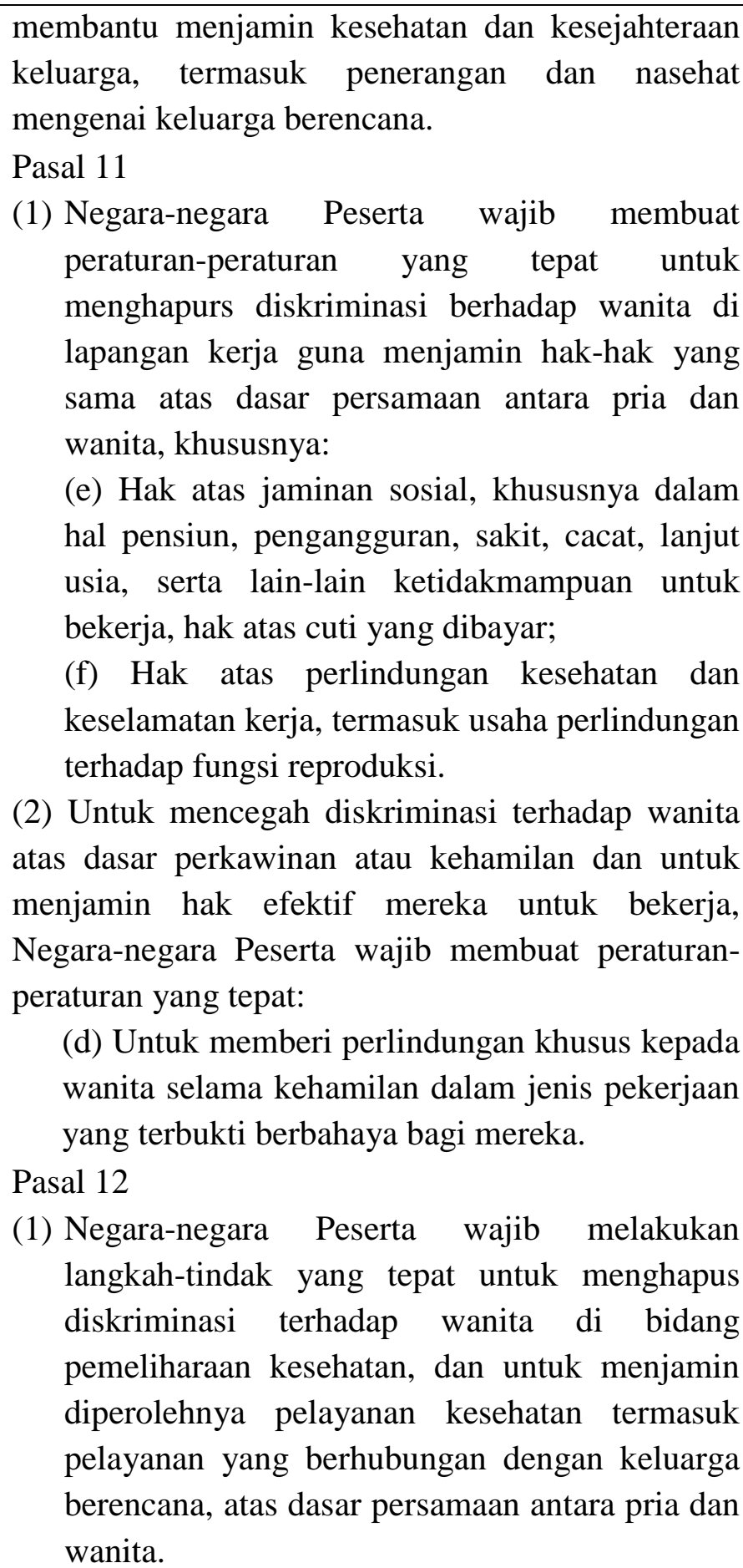 \\
\hline
\end{tabular}




\begin{tabular}{|l}
\hline (2) Sekalipun terdapat ketentuan pada ayat (1) ini, \\
negara-negara Peserta wajib menjamin bahwa \\
wanita mendapat pelayanan yang layak \\
berkaitan dengan kehamilan, persalinan dan \\
masa sesudah persalinan, dengan memberikan \\
pelayanan cuma-cuma di mana perlu, serta \\
pemberian makanan bergizi yang cukup selama \\
kehamilan dan menyusui. \\
Pasal 14 \\
(2) Negara-negara Peserta wajib melakukan \\
langkah-tindak yang tepat untuk menghapus \\
diskriminasi terhadap wanita di daerah \\
perdesaan, dan menjamin bahwa mereka ikut \\
serta dalam menikmati manfaatdari \\
pembangunan perdesaan atas dasar persamaan \\
antara pria dan wanita, khususnya menjamin \\
kepada wanita perdesaan hak: \\
(b) Untuk memperoleh fasilitas pemeliharaan \\
kesehatan yang memadai, termasuk penerangan, \\
penyuluhan dan pelayanan dalam keluarga \\
berencana. \\
Bagian IV, Pasal 16 \\
(1) Negara-negara Peserta wajib melakukan \\
langkah-tindak yang tepat untuk menghapus \\
diskriminasi terhadap wanita dalam semua \\
urusan yang berhubungan dengan perkawinan \\
dan hubungan keluarga atas dasar persamaan \\
antara pria dan wanita, dan khususnya akan \\
menjamin: \\
(e) Hak yang sama untuk menentukan secara \\
bebas dan bertanggung jawab jumlah dan \\
penjarakan kelahiran anak-anak mereka serta \\
untuk memperoleh penerangan, pendidikan dan \\
sarana-sarana untuk memungkinkan mereka
\end{tabular}




\begin{tabular}{|l|l|}
\hline & \multicolumn{2}{|c|}{ menggunakan hak-hak ini. } \\
\hline 3. & $\begin{array}{l}\text { The International United Nations Conference on } \\
\text { Population and Development (ICPD), Cairo, 1994 }\end{array}$ \\
\hline
\end{tabular}

Terhadap International United Nations Conference on Population and Development (ICPD) atau Hak-Hak Reproduksi dan Kesehatan Reproduksi memiliki tujuan sebagai berikut: ${ }^{22}$

a. Untuk memastikan bahwa informasi yang menyeluruh dan faktual serta beraneka jenis pelayanan pemeliharaan kesehatan reproduksi, termasuk perencanaan keluarga, tersedia, terjangkau, dapat diterima, dan cocok untuk semua pemakai;

b. Untuk memungkinkan dan mendukung keputusan sukarela dan bertanggung jawab dalam hal kehamilan dan metode keluarga berencana pilihan mereka dan metode lain pilihan mereka dalam hal pengaturan kesuburan yang tidak bertentangan dengan hukum serta mempunyai informasi, pendidikan dan cara memperolehnya;

c. Untuk memenuhi kebutuhan-kebutuhan kesehatan reproduksi yang mengalami perubahan sepanjang siklus hidup dan melakukan hal itu dengan cara yang peka terhadap keanekaragaman keadaan masyarakat setempat.

Terhadap hukum nasional di Indonesia yang mengatur mengenai pelaksanaan pemenuhan dan perlindungan hak kesehatan reproduksi, yaitu:

Tabel 4: Aturan Nasional terhadap Hak

Kesehatan Reproduksi

\begin{tabular}{|c|l|l|l|}
\hline No. & \multicolumn{4}{|c|}{ Regulasi dan Pasal Terkait } \\
\hline 1. & $\begin{array}{l}\text { Undang-Undang Republik Indonesia } \\
\text { Tahun 1974 tentang Perkawinan }\end{array}$ & Nomor 1 \\
\hline 2. & $\begin{array}{l}\text { Undang-Undang Republik Indonesia } \\
\text { Tahun } \mathbf{1 9 8 4} \text { Nomor } \\
\text { Mengenai Penghapusan Segala Bentuk Diskriminasi }\end{array}$ \\
\hline
\end{tabular}

22 Terjemahan International United Nations Conference on Population and Development (ICPD) 


\begin{tabular}{|c|c|}
\hline & $\begin{array}{l}\text { Terhadap Wanita (Convention on the Elimination of } \\
\text { All Forms of Discrimination Against } \\
\text { Women/CEDAW) }\end{array}$ \\
\hline 3. & $\begin{array}{l}\text { Undang-Undang Republik Indonesia Nomor } 39 \\
\text { Tahun } 1999 \text { tentang Hak Asasi Manusia } \\
\text { - Pasal } 49 \\
\text { (2) Wanita berhak untuk mendapatkan perlindungan } \\
\text { khusus dalam pelaksanaan pekerjaan atau } \\
\text { profesinya terhadap hal-hal yang dapat mengancam } \\
\text { keselamatan dan atau kesehatannya berkenaan } \\
\text { dengan fungsi reproduksi wanita. } \\
\text { (3) Hak khusus yang melekat pada diri wanita } \\
\text { dikarenakan fungsi reproduksinya, dijamin dan } \\
\text { dilindungi oleh hukum. }\end{array}$ \\
\hline 4. & $\begin{array}{l}\text { Undang-Undang Republik Indonesia Nomor } 13 \\
\text { Tahun } 2003 \text { tentang Ketenagakerjaan } \\
\text { - } \text { Pasal } 35 \\
\text { (3) Pemberi kerja sebagaimana dimaksud dalam } \\
\text { ayat (1) dalam mempekerjakan tenaga kerja wajib } \\
\text { memberikan perlindungan yang mencakup } \\
\text { kesejahteraan, keselamatan, dan kesehatan baik } \\
\text { mental maupun fisik tenaga kerja. } \\
\text { - Pasal } 81 \\
\text { (1) Pekerja/buruh perempuan yang dalam masa haid } \\
\text { merasakan sakit dan memberitahukan kepada } \\
\text { pengusaha, tidak wajib bekerja pada hari pertama } \\
\text { dan kedua pada waktu haid. } \\
\text { Pasal } 82 \\
\text { (1) Pekerja/buruh perempuan berhak memperoleh } \\
\text { istirahat selama } 1,5 \text { (satu setengah) bulan sebelum } \\
\text { saatnya melahirkan anak dan 1,5 (satu setengah) } \\
\text { bulan sesudah melahirkan menurut perhitungan } \\
\text { dokter kandungan atau bidan. } \\
\text { (2) Pekerja/buruh perempuan yang mengalami }\end{array}$ \\
\hline
\end{tabular}




\begin{tabular}{|c|c|}
\hline & $\begin{array}{l}\text { keguguran kandungan berhak memperoleh istirahat } \\
1,5 \text { (satu setengah) bulan atau sesuai dengan surat } \\
\text { keterangan dokter kandungan atau bidan. }\end{array}$ \\
\hline 5. & $\begin{array}{l}\text { Undang-Undang Republik Indonesia Nomor } 36 \\
\text { Tahun } 2009 \text { tentang Kesehatan } \\
\text { - } \text { Pasal } 48 \\
\text { (1) Penyelenggaraan upaya kesehatan sebagaimana } \\
\text { dimaksud dalam Pasal } 47 \text { dilaksanakan melalui } \\
\text { kegiatan: } \\
\text { (e) Kesehatan Reproduksi } \\
\text { - Pasal } 71 \\
\text { (1) Kesehatan reproduksi merupakan keadaan sehat } \\
\text { secara fisik, mental, dan sosial secara utuh, tidak } \\
\text { semata-mata bebas dari penyakit atau kecacatan } \\
\text { yang berkaitan dengan sistem, fungsi, dan proses } \\
\text { reproduksi pada laki-laki dan perempuan. } \\
\text { (2) Kesehatan reproduksi sebagaimana dimaksud } \\
\text { pada ayat (1) meliputi: } \\
\text { a. saat sebelum hamil, hamil, melahirkan, dan } \\
\text { sesudah melahirkan; } \\
\text { b. pengaturan kehamilan, alat kontrasepsi, dan } \\
\text { kesehatan seksual; dan } \\
\text { c. kesehatan sistem reproduksi. } \\
\text { (3) Kesehatan reproduksi sebagaimana dimaksud } \\
\text { pada ayat (2) dilaksanakan melalui kegiatan } \\
\text { promotif, preventif, kuratif, dan rehabilitatif. } \\
\text { Pasal } 72 \\
\text { Setiap orang berhak: } \\
\text { a. menjalani kehidupan reproduksi dan kehidupan } \\
\text { seksual yang sehat, aman, serta bebas dari paksaan } \\
\text { dan/atau kekerasan dengan pasangan yang sah. } \\
\text { b. menentukan kehidupan reproduksinya dan bebas } \\
\text { dari diskriminasi, paksaan, dan/atau kekerasan yang } \\
\text { menghormati nilai-nilai } \\
\text { luhur yang tidak }\end{array}$ \\
\hline
\end{tabular}




\begin{tabular}{|c|c|}
\hline & 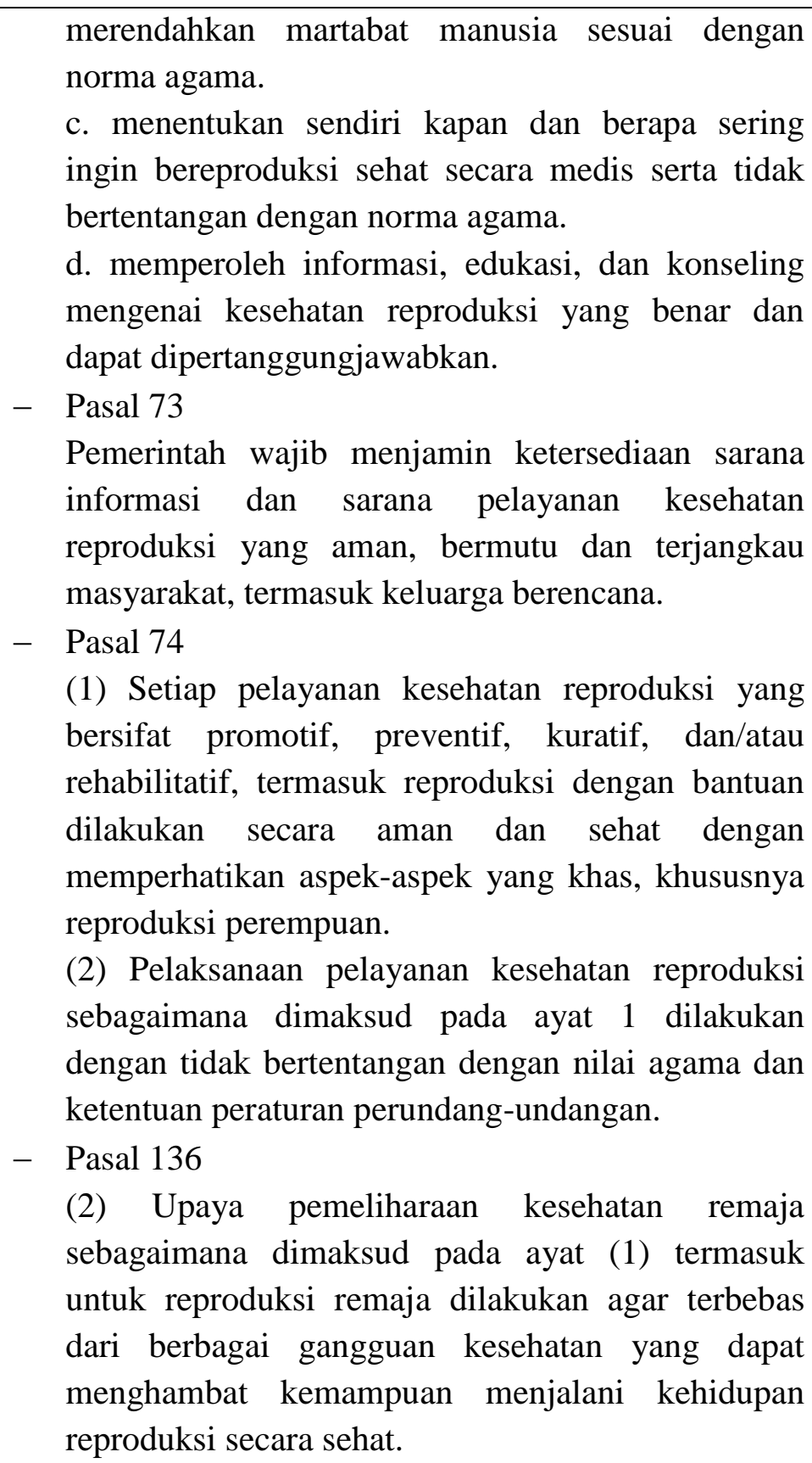 \\
\hline 6. & $\begin{array}{lrrr}\text { Undang-Undang } & \text { Republik } & \text { Indonesia Nomor } 52 \\
\text { Tahun } 2009 & \text { Tentang } & \text { Perkembangan } \\
\text { Kependudukan dan Pembangunan Keluarga }\end{array}$ \\
\hline
\end{tabular}




\begin{tabular}{|l|l|}
\hline Pasal 1 \\
8. Keluarga Berencana adalah upaya mengatur \\
kelahiran anak, jarak dan usia ideal melahirkan, \\
mengatur kehamilan, melalui promosi, \\
perlindungan, dan bantuan sesuai dengan hak \\
reproduksi untuk mewujudkan keluarga yang \\
berkualitas. \\
- Pasal 21 \\
(1) Kebijakan keluarga berencana sebagaimana \\
dimaksud dalam Pasal 20 dilaksanakan untuk \\
membantu calon atau pasangan suami istri dalam \\
mengambil keputusan dan mewujudkan hak \\
reproduksi secara bertanggung jawab tentang: \\
a. usia ideal perkawinan; \\
b. usia ideal untuk melahirkan; \\
c. jumlah ideal anak; \\
d. jarakideal kelahiran anak; dan \\
e. penyuluhan kesehatan reproduksi. \\
(2) Kebijakan keluarga berencana sebagaimana \\
dimaksud pada ayat (1) bertujuan untuk: \\
a. mengatur kehamilan yang diinginkan; \\
b. menjaga kesehatan dan menurunkan angka \\
kematian ibu, bayi dan anak; \\
c. meningkatkan akses dan kualitas informasi, \\
pendidikan, konseling, dan pelayanan keluarga \\
berencana dan kesehatan reproduksi; \\
d. meningkatkan partisipasi dan kesertaan pria \\
dalam praktek keluarga berencana; dan \\
e. mempromosikan penyusuan bayi sebagai upaya \\
untuk menjarangkan jarak kehamilan. \\
(3) Kebijakan keluarga berencana sebagaimana \\
dimaksud pada ayat (1) mengandung pengertian \\
bahwa dengan alasan apapun promosi aborsi \\
sebagai pengaturan kehamilan dilarang. \\
\hline
\end{tabular}




\begin{tabular}{|l|l|}
\hline 7. & Peraturan Pemerintah Republik Indonesia Nomor \\
61 Tahun 2014 Tentang Kesehatan Reproduksi \\
- \\
Pasal 1 \\
2. Kesehatan Reproduksi adalah keadaan sehat \\
secara fisik, mental, dan sosial secara utuh, tidak \\
semata-mata bebas dari penyakit atau kecacatan \\
yang berkaitan dengan sistem, fungsi, dan proses \\
reproduksi. \\
- \\
Pasal 2 \\
Ruang lingkup pengaturan Kesehatan Reproduksi \\
dalam Peraturan Pemerintah ini meliputi: \\
a. pelayanan kesehatan ibu; \\
b. indikasi kedaruratan medis dan perkosaan \\
sebagai pengecualian atas larangan aborsi; dan \\
c. Reproduksi dengan Bantuan atau Kehamilan di \\
luar cara alamiah. \\
Pasal 3 \\
Pengaturan Kesehatan Reproduksi bertujuan untuk: \\
a. menjamin pemenuhan hak Kesehatan Reproduksi \\
setiap orang yang diperoleh melalui pelayanan \\
kesehatan yang bermutu, aman, dan dapat \\
dipertanggungjawabkan; dan \\
b. menjamin kesehatan ibu dalam usia reproduksi \\
agar mampu melahirkan generasi yang sehat dan \\
berkualitas serta mengurangi angka kematian ibu. \\
Pasal 8 \\
(1) Setiap perempuan berhak mendapatkan \\
pelayanan kesehatan ibu untuk mencapai hidup \\
sehat dan mampu melahirkan generasi yang sehat \\
dan berkualitas serta mengurangi angka kematian \\
ibu. \\
(2) Pelayanan kesehatan ibu sebagaimana dimaksud \\
pada ayat (1) dilakukan sedini mungkin dimulai \\
dari masa remaja sesuai dengan perkembangan
\end{tabular}




\begin{tabular}{|l|l|}
\hline mental dan fisik. \\
(3) Pelayanan kesehatan ibu sebagaimana dimaksud \\
pada ayat (2) diselenggarakan melalui: \\
a. Pelayanan Kesehatan Reproduksi Remaja; \\
b. Pelayanan Kesehatan Masa Sebelum Hamil, \\
Hamil, Persalinan, dan Sesudah Melahirkan; \\
c. pengaturan kehamilan, pelayanan kontrasepsi dan \\
kesehatan seksual; dan \\
d. Pelayanan Kesehatan Sistem Reproduksi. \\
- Pasal 20 \\
(1) Setiap orang berhak mendapatkan komunikasi, \\
informasi, dan edukasi tentang keluarga berencana. \\
- Pasal 22 \\
(1) Setiap orang berhak memilih metode \\
kontrasepsi untuk dirinya tanpa paksaan. \\
Pasal 26 \\
(1) Setiap perempuan berhak menjalani kehidupan \\
seksual yang sehat secara aman, tanpa paksaan dan \\
diskriminasi, tanpa rasa takut, malu, dan rasa \\
bersalah. \\
- Pasal 30 \\
(1) Setiap perempuan berhak atas Pelayanan \\
Kesehatan Sistem Reproduksi. \\
(2) Pelayanan Kesehatan Sistem Reproduksi \\
sebagaimana dimaksud pada ayat (1) ditujukan \\
untuk melindungi organ dan fungsi reproduksi agar \\
terbebas dari gangguan, penyakit atau kecacatan \\
pada perempuan. \\
(3) Pelayanan Kesehatan Sistem Reproduksi \\
sebagaimana dimaksud pada ayat (1) dilakukan \\
dengan memperhatikan tahapan siklus reproduksi \\
perempuan sesuai standar. \\
\end{tabular}


Banyaknya regulasi yang mengatur tentang hak kesehatan reproduksi harusnya berimplikasi pada sedikitnya jumlah angka penderita kanker serviks ataupun angka kematian ibu melahirkan. Hal ini dikarenakan banyaknya perempuan yang tidak mengetahui haknya. Dalam kehidupan perempuan persoalan hak sangat langka dibicarakan, bahkan untuk urusan reproduksi masih di anggap sebagai tabu untuk di bicarakan oleh orang tua pada anaknya.

Fungsi reproduksi perempuan hanya berada pada wilayah domestik, sehingga perempuan terbiasa dengan berbagai kewajiban sebagai seorang ibu atau istri. Seharusnya demi tercapainya derajat kesehatan yang tinggi, maka perempuan wajib mengetahui persoalan kesehatan, agar dapat berperan sebagai pemberi kesehatan dalam keluarga.

\section{Perlindungan Hak Reproduksi Perempuan di Provinsi Riau}

Kesehatan reproduksi perempuan sudah diakui oleh badan dunia yang mengurus kesehatan, yaitu WHO. Hak reproduksi ini juga sudah dikukuhkan dalam Deklarasi HAM tahun 1968 di Teheran, Deklarasi Meksiko tahun 1975 sebagai hasil Konferensi Wanita sedunia yang pertama, dan yang diperkuat terus dalam Konferensi Wanita Sedunia yang ke-2 di Kopenhagen, ke-3 di Nairobi, dan ke-4 di Beijing. Pemenuhan pelayanan kesehatan reproduksi juga dijamin dalam Konvensi Penghapusan Segala Bentuk Diskriminasi Terhadap Wanita (Konvensi Wanita) atau Convention on the Elimination of all form of Discrimination against Women (CEDAW), diratifikasi oleh Indonesia, dengan UndangUndang Nomor 7 tahun 1984, khususnya Pasal 12. ${ }^{23}$

Dalam Pasal 12 ayat 2 Konvensi Wanita ini, jelas sekali diatur mengenai kewajiban Negara yang menjamin tersedianya pelayanan kesehatan reproduksi perempuan, yang dijamin oleh undang-undang, yaitu $:^{24}$

23 Sulistyiowati Irianto (ed), Perempuan Dan Hukum Menuju Hukum Yang Berperspektif Kesetaraan dan Keadilaan, Buku Obor, Jakarta, 2008, h. 528

${ }^{24}$ Ibid, h. 529 
a. Memastikan pelayanan yang layak untuk perempuan dalam hubungannya dengan kehamilan, persalinan dan periode pasca persalinan, bila perlu menyediakan pelayanan gratis.

b. Memastikan perempuan mendapatkan gizi yang cukup selama masa kehamilan dan menyusui.

Bila kita kaitkan semua instrumen hukum yang ada dengan kesepakatan global serta deklarasi ICPD Kairo 1994 dan Beijing 1995, lengkaplah sudah perlindungan hak dan kesehatan reproduksi perempuan, apalagi bila ditambah pula dengan Rekomendasi Umum Nomor 24 yang berkaitan dengan Konvensi CEDAW Pasal 12 tentang kesehatan, (Sesi ke 20 sidang PBB tahun 1999), Pasal 31,c,d,e dan f yang menetapkan : $:^{25}$

Negara-negara peserta Konvensi juga harus, khususnya

a. Memprioritaskan pencegahan kehamilan yang tidak dikehendaki melalui keluarga berencana dan pendidikan seks dan mengurangi tingkat kematian ibu melalui layanan ibu yang aman dan bantuan prenatal. Bilamana mungkin instrumen hukum yang mempidana aborsi perlu dirubah, untuk menarik tindakan punitif yang dikenakan kepada perempuan yang menjalani aborsi;

b. Mengawasi pemberian layanan kesehatan kepada perempuan oleh lembaga-lembaga publik, non pemerintah dan swasta, guna menjamin akses yang setara dan kualitas pelayanan;

c. Mengharuskan semua layanan kesehatan agar sesuai dengan hak-hak asasi perempuan, termasuk hak atas otonomi, privasi, kerahasiaan, persetujuan berdasarkan pengetahuan (informed consent) dan pilihan;

d. Memastikan bahwa kurikulum pelatihan pekerja kesehatan mencakup pelajaran-pelajaran yang menyeluruh, wajib dan peka gender terutama yang berkaitan dengan kesehatan perempuan dan hak asasi manusia, khususnya kekerasan berbasis gender.

${ }^{25}$ Ibid, h. 530 
Berdasarkan Kesepakatan Konferensi Internasional Kependudukan dan Pembangunan tahun 1994 di Kairo, pemerintah Indonesia telah menyetujui 12 (dua belas) hak reproduksi yang di dalamnya termasuk hak-hak reproduksi perempuan, yaitu:

1. Hak untuk mendapatkan informasi dan pendidikan kesehatan reproduksi. Setiap perempuan berhak untuk mendapatkan informasi dan pendidikan yang jelas dan benar tentang berbagai aspek terkait dengan masalah kesehatan reproduksi, termasuk banyakanya pilihan alat kontrasepsi yang dapat dipilih oleh perempuan atau lakilaki dan efek samping dari berbagai alat kontrasepsi;

2. Hak untuk mendapatkan pelayanan dan perlindungan kesehatan reproduksi. Setiap perempuan berhak untuk mendapatkan pelayanan kesehatan dan perlindungan yang memadai bagi kehidupan reproduksinya, termasuk agar terhindar dari kematian akibat proses reproduksi, misalnya jaminan kesehatan agar perempuan terhindar dari kematian akibat kehamilan atau melahirkan. Hak ini tidak boleh dibedakan atau didiskriminasikan berdasarkan status perkawinan perempuan atau usia atau status ekonominya. Semua perempuan baik remaja, maupun yang berstatus menikah berhak untuk mendapatkan dan menikmati hak ini.

3. Hak untuk Kebebasan Berpikir Tentang Hak Reproduksi. Setiap perempuan berhak untuk mengungkapkan fikiran dan keyakinnya untuk menjaga kesehatan dan kehidupan reproduksinya tanpa paksaan dari siapapun;

4. Hak untuk menentukan jumlah anak dan jarak kelahiran. Setiap perempuan berhak untuk menentukan jumlah anak yang akan dilahirkannya serta menentukan jarak kelahiran anak yang diinginkannya, tanpa paksaan dari siapapun;

5. Hak untuk hidup, yaitu hak untuk dilindungi dari kematian karena kehamilan dan proses melahirkan. Setiap perempuan hamil dan yang akan melahirkan berhak untuk mendapatkan perlindungan termasuk pelayanan kesehatan yang baik sehingga ia dapat mengambil keputusan secara 
cepat mengenai kelanjutan kehamilannya bila proses kelahirannya beresiko kematian atau terjadi komplikasi.

6. Hak atas kebebasan dan keamanan berkaitan dengan kehidupan reproduksi. Artinya setiap perempuan harus dijamin agar tidak mengalami pemaksaan, pengucilan, dan tekanan yang menyebabkan kebebasan dan keamanan yang diperolehnya tidak dapat digunakan, termasuk kebebasan memilih alat kontrasepsi yang dianggapnya paling aman.

7. Hak untuk bebas dari penganiayaan dan perlakuan buruk, termasuk perlindungan dari perkosaan, kekerasan, penyiksaan, dan pelecehan seksual. Setiap perempuan berhak untuk dilindungi dari ancaman bentuk-bentuk kekerasan yang dapat menimbulkan penderitaan secara fisik, seksual, dan psikis yang mengganggu kesehatan fisik, mental, dan reproduksinya.

8. Hak untuk mendapatkan manfaat dari kemajuan ilmu pengetahuan yang terkait dengan kesehatan reproduksi. setiap perempuan berhak untuk memanfaatkan kemajuan teknologi dan ilmu pengetahuan terkait dengan kesehatan reproduksi, misalnya informasi yang jelas dan benar serta kemudahan akses untuk mendapatkan alat kontrasepsi baru

9. Hak atas kerahasiaan pribadi dengan kehidupan reproduksinya. Setiap perempuan berhak untuk dijamin kerahasiaan kesehatan reproduksinya, mislanya informasi tentang kehidupan seksualnya, masa menstruasi, jenis alat kontrasepsi yang digunakan.

10. Hak untuk membangun dan merencanakan keluarga. Setiap perempuan berhak untuk menentukan kapan, dimana, dengan siapa, serta bagaimana ia akan membangun perkawinan atau keluarganya.

11. Hak atas kebebasan berkumpul dan berpartisipasi dalam politik yang berkaitan dengan kesehatan reproduksi. Setiap perempuan berhak untuk menyampaikan pendapat 
atau aspirasinya mengenai kehidupan reproduksi secara pribadi atau melalui organisasi atau partai.

12. Hak untuk bebas dari segala bentuk diskriminasi dalam kehidupan berkeluarga dan kehidupan reproduksi. Setiap perempuan berhak untuk terbebaskan dari perlakuan diskriminasi berdasarkan gender/perbedaan jenis kelamin, ras, status perkawinan atau kondisi sosialekonomi, agama/keyakinannya dalam kehidupan keluarga dan proses reproduksinya. Misalnya, orang tidak mampu harus mendapatkan pelayanan kesehatan reproduksi yang berkualitas, demikian pula remaja yang hamil di luar nikah.

Pemerintah Provinsi Riau juga berupaya memberikan perlindungan terhadap hak kesehatan reproduksi, khususnya perempuan. Pemerintah Provinsi Riau menyadari bahwa pemerintah berkewajiban untuk melindungi dan menjamin agar hak-hak reproduksi individu tidak dilanggar dan dapat digunakan oleh setiap orang yang memiliki hak tersebut.

Upaya-upaya yang sudah dilakukan oleh Pemerintah Provinsi Riau terhadap hak kesehatan repoduksi adalah:

1. Upaya Preventif

a. Memberikan Pendidikan Kesehatan Reproduksi Usia Dini

Pemerintah melalui Dinas Kesehatan Provinsi dan Kabupaten/Kota bekerja sama dengan Rumah Sakit Umum Daerah (RSUD) dan Puskesmas setempat dalam hal melakukan sosialisasi dan penyuluhan untuk memberikan pendidikan kesehatan reproduksi usia dini. Dalam pelaksanaan kegiatan tersebut juga melibatkan bantuan dari perusahaan pembalut yang bersedia bekerja sama dalam melakukan kegiatan tersebut.

Peserta dalam kegiatan ini adalah pelajar Sekolah Menengah Pertama (SMP) dan Sekolah Menengah Atas (SMA) yang ada di Provinsi Riau. Tujuan dari kegiatan ini adalah untuk memberikan pemahaman kepada siswa dalam mencegah penyakit kanker serviks pada 
khususnya dan dapat melakukan aktifitas kebersihan pada organ vital mereka pada umumnya.

b. Menyediakan Pelayanan Kesehatan Reproduksi dan Perempuan di PUSKESMAS

Pemerintah juga menyediakan fasilitas pelayanan kesehatan reproduksi dan perempuan, khususnya untuk ibu hamil dan menyusui di puskesmas yang ada di Provinsi Riau. Hal ini dilakukan untuk memberikan pemahaman bagi perempuan dalam menjaga kesehatan reproduksinya. Selain itu juga memudahkan bagi perempuan untuk mengetahui gejala-gejala penyakit kelamin serta upaya yang dapat dilakukan untuk mengatasi penyakit tersebut.

c. Program Bidan Desa

Program mengurangi angka kematian ibu dan bayi yang dilakukan oleh pemerintah adalah menempatkan bidan-bidan di desa. Tujuan kegiatan ini adalah untuk mengurangi minat masyarakat melakukan proses persalinan pada dukun kampung. Bidan Desa dan Dukun Kampung menjadi mitra kerja dalam proses persalinan. Hal ini dilakukan karena masih banyak masyarakat yang lebih percaya melahirkan dengan bantuan dukun kampung.

Pada dasarnya Dukun Kampung di ajak bekerjasama dalam menangani proses persalinan, sehingga dalam program ini tidak ada pihak yang dirugikan. Hubungan antara Bidan Desa dengan Dukun Kampung adalah tim/mitra kerja dalam proses persalinan, bukan merupakan persaingan kerja.

d. Program Keluarga Berencana

Program Keluarga Berencana adalah program utama pemerintah dalam mengatasi angka kematian ibu melahirkan dan angka kematian bayi. Selain itu juga mengatasi laju pertambahan penduduk. Fokus terpenting dari program ini adalah penyediaan pelayanan kesehatan reproduksi yang menyeluruh, yang memadukan Keluarga Berencana, pelayanan kehamilan dan persalinan yang aman, pencegahan pengobatan infeksi menular seksual/IMS (termasuk HIV), informasi 
dan konseling seksualitas, serta pelayanan kesehatan perempuan mendasar lainnya.

e. Kebijakan-kebijakan

Kondisinya saat ini adalah Pemerintah Provinsi Riau belum memilik Peraturan Daerah tentang Hak Kesehatan Reproduksi, tetapi beberapa kebijakan dan regulasi yang berkaitan dengan hak kesehatan reproduksi sudah ada bahkan sudah diterapkan dalam lingkungan Provinsi Riau.

2. Upaya Represif

a. Program Imunisasi Kanker Serviks

Program ini dilakukan oleh Pemerintah Provinsi Riau baik secara gratis ataupun subsidi dari pemerintah. Kegiatan ini dilakukan untuk mencegah atau mengurangi penderita kanker serviks.

b. Peningkatan Penyediaan Sarana dan Prasarana

Pemerintah Provinsi Riau juga menyediakan fasilitas sarana dan prasarana sebagai upaya pemerintah terhadap pemenuhan hak kesehatan reproduksi. Berbagai alat-alat kesehatan diupayakan untuk ditingkatkan keberadaannya hingga ke puskesmas desa. Hal ini bertujuan agar masyarakat yang berada di desa, tetap dapat terfasilitasi hak-hak kesehatannya, terutama kesehatan reprokdusi.

\section{Kesimpulan}

1. Regulasi yang mengatur tentang pemenuhan hak kesehatan reproduksi tidak hanya tertulis dalam regulasi tingkat nasional, tetapi juga dalam regulasi internasional. Hal ini menandakan bahwa pengakuan akan hak kesehatan reproduksi bersifat universal. Sehinga negara berkewajiban untuk memenuhi pelaksanaan dan perlindungan dari hak kesehatan reproduksi tersebut.

2. Perlindungan hak kesehatan reproduksi di Provinsi Riau dilakukan dalam bentuk upaya preventif dan represif. Upaya preventif, yaitu: memberikan pendidikan kesehatan reproduksi usia dini, menyediakan pelayanan kesehatan reproduksi dan perempuan di Puskesmas, program Bidan desa, Program Keluarga Berencana, dan 
membuat kebijakan. Sementara upaya represifnya adalah program imunisasi kanker serviks dan peningkatan penyediaan sarana dan prasarana.

\section{Daftar Pustaka}

Baehr, Peter R. Hak-Hak Asasi Manusia Dalam politik Luar Negeri, diterjemahkan oleh Soemardi,, Yayasan Obor Indonesia, Jakarta, 1998

Baso, Zora Adi dan Judi Raharjo, Kesehatan Reproduksi Panduan bagi Perempuan, Pustaka Belajar, Sulawesi Selatan, 1999

Davidson, Scott, Hak Asasi Manusia: Sejarah, Teori Dan Praktek Dalam Pergaulan Internasional, diterjemahkan oleh A. Hadyana Pudjaatmaka, Pustaka Utama Grafiti, Jakarta, 1994

Ihromi, Tapi Omas (ed), Penghapusan Diskriminasi Terhadap Perempuan, PT.Alumni, Bandung, 2006

Irianto, Sulistyiowati (ed), Perempuan Dan Hukum Menuju Hukum Yang Berperspektif Kesetaraan dan Keadilaan, Buku Obor, Jakarta, 2008

Irsan, Koesparmono, Hukum dan Hak Asasi Manusia, Yayasan Brata Bhakti, Jakarta, 2009

Kartono, Kartini, Psikologi Wanita 2, Mandar Maju, Bandung, 2007

Kelsen, Hans, General Theory of Law and State, diterjemahkan oleh Raisul Mutaqien menjadi Teori Umum tentang Hukum dan Negara, penerbit Nuamedia \& penerbit Nuansa, Bandung, 2006

Kosasi, Ahmad, HAM Dalam Perspektif Islam; Menyingkap Persamaan Dan Perbedaan Antara Islam Dan Barat, Salemba Diniyah, Jakarta, 2003

Mahfina, Layyin, Elfi Yuliani Rohmah, Retno Widyaningrum, Remaja dan Kesehatan Reproduksi, STAIN Ponorogo, Yogyakarta, 2009 
Mertokusumo, Sudikno, Mengenal Hukum; Suatu Pengantar, Liberty, Yogyakarta, 1999

Negara, Made Okara, Mengurangi Persoalan Kehidupan Seksual dan Reproduksi Perempuan dalam Jurnal Perempuan cetakan No.41, Yayasan Jurnal Perempuan, Jakarta, 2005

Paton, George Ehitecros, A Text-Book of Jurisprudance, Off Gray's inn, Barrister et law vice-Chancellor of the University of malbourne, terjemahan G. Soedarsono, dkk, Jajasan B.P. Gajah Mada Jogjakarta,t.t.

Soekanto, Soejono, Pengantar Penelitian Hukum, Ui-Press, Jakarta, 2006

Zoelfirman, Kebebasan Berkontrak Versus Hak Asasi Manusia (Analisis Yuridis Hak Ekonomi, Sosial, Dan Budaya), UISU Press, Medan, 2003

Tim Penyusun Kamus Departemen Pendidikan Dan Kebudayaan RI, Kamus Besar Bahasa Indonesia, Jakarta, 1988

Terjemahan International United Nations Conference on Population and Development (ICPD) 